\title{
COMMENTARY
}

\section{Gut instinct}

\author{
Julian Bion \\ See related research by Cuthbertson et al., http://ccforum.com/content/17/6/R266
}

\begin{abstract}
Barriers to the use of selective digestive decontamination include concerns about emergence of resistant organisms, over-estimation of current performance in preventing ventilator-associated pneumonia (VAP), alternative methods of preventing VAP, and misunderstanding of mechanisms of action. A definitive cluster-randomised trial should be undertaken that incorporates practitioner concerns and effect-size preferences.
\end{abstract}

In this issue of Critical Care, Cuthbertson and colleagues report [1] the views of 141 intensive care and infection control specialists from four countries on the potential utility, risks and research opportunities of selective digestive decontamination (SDD). Using structured interviews, a Delphi process, and a theoretical behavioural domains framework, they determined the extent of consensus and perceived importance of specific issues relating to SDD.

Respondents demonstrated substantial equipoise on risks and benefits of SDD combined with moderate agreement on concerns that SDD might contribute to antimicrobial resistance. There was uncertainty about the generalisability of SDD research to local context or to all patient groups, and moderately strong support for participating in a national randomised controlled trial of SDD despite a common view that SDD was not a high clinical priority, presumably related to the reported use of other strategies to minimise healthcare-associated infections and ventilator-associated pneumonia (VAP).

SDD is unique amongst intensive care interventions in having the largest and most consistent evidence base for benefit in terms of minimising secondary infections and reducing mortality. Since the initial publications by Stoutenbeek and van Saene in 1983 and 1984 [2,3]

Correspondence: J.F.BION@bham.ac.uk

University Department of Intensive Care, East Ground, Queen Elizabeth Hospital (old site), Edgbaston, Birmingham B15 2TH, UK describing SDD in mechanically ventilated trauma patients, there have been at least 65 randomised controlled trials and 12 meta-analyses involving around 15,000 patients. No other intervention approaches this weight of evidence, and yet expert opinion frequently disregards the technique. SDD was omitted from the first consensus statement of the Surviving Sepsis Campaign [4]; in the second iteration [5] SDD was considered but no recommendation made, since expert opinion was shown to be bimodal, demonstrated through the development of the GRADE Grid [6]. In the third iteration in 2012-2013 [7], SDD has achieved a level $2 \mathrm{~B}$ recommendation (suggested use based on 'moderate evidence'). What are the reasons for this gap between evidence and uptake?

The main barrier to SDD relates to the perceived risk of antimicrobial resistance (or emergence of species not covered by the traditional regimen, such as Grampositive bacteria) if SDD were to be widely adopted, with the spread of these organisms to the wider environment. The historical over-use of antimicrobials (intravenous and oral in humans, as growth promoters in animals) has led to calls for better antimicrobial stewardship, and doctors are now conditioned to minimise frequency and duration of prescriptions. Prolonged use of prophylactic antimicrobials therefore appears to run counter to this philosophy. In the current survey respondents tended to support the statements that SDD increases antimicrobial resistance and that research to date has not adequately addressed this issue. However, recent studies [8-12] do not support either position; in the two largest trials, rates of resistance were lower in the SDD group $[8,10]$. Indeed, it is the conventional use of broad-spectrum intravenous antimicrobials that may promote the emergence of resistance by creating sub-lethal concentrations of antimicrobials in the gut, which then becomes a reservoir of pathogenic aerobic organisms in critically ill patients. This suggests the possibility that SDD may not only be unlikely to promote resistance, but also might actually prevent their emergence.

The second barrier relates to local perceptions of performance: the sense that SDD is not required because 
hospital acquired infections are already well-controlled. The majority of respondents agreed with the statement that 'Our VAP rates are low'. This may be the case if ICUs are regularly auditing their VAP rates. However, as we found in the Matching Michigan project [13-15], many ICUs were surprised to find that their performance in minimising blood stream infections from central venous catheters was not as good as they had expected.

The third barrier may be the availability of 'competing' non-antimicrobial interventions for preventing VAP in mechanically ventilated patients, often combined in 'VAP bundles'. SDD should be compared with these nonantimicrobial approaches to determine whether there is synergy, or whether the newer techniques can substitute for SDD.

The final barrier to SDD might be uncertainty about who should receive it, in what form and with which components. Originally promoted as a technique for preventing gut overgrowth with potentially pathogenic Gram-negative aerobes by preserving the normal colonic anaerobic flora [2], it gradually came to be seen primarily as a technique for preventing VAP from retrograde oropharyngeal spread of enteric organisms. The classical nosocomial Gram-negative pathogens of the 1980s were replaced in the 1990s and 2000s by resistant Grampositives for which SDD was not specifically designed; in recent years multiply-resistant Gram-negatives have returned. This means that the SDD regimen must be adapted to local circumstance - for example, including enteral vancomycin or modifying the anti-Gram-negative components. Evolving concepts of the mechanism(s) of action of SDD now re-emphasise the gut as the primary reservoir of pathogenic organisms, and establishment of normal enteric flora as the main therapeutic aim $[16,17]$. To this extent SDD and interventions directed at increasing splanchnic blood flow share the same conceptual framework of the gut as 'the largest undrained abscess in the body'.

One question that the survey did not directly ask is 'what evidence and effect size would encourage you to use SDD as a routine intervention in mechanically ventilated patients?' The answer to this is likely to include the absence of emergence of resistance over several years (at both the individual and environmental level) and improvements in survival to at least 1 year. It is clear that the research will need to compare SDD against non-antimicrobial interventions directed against VAP, and will need to take into account local microbial ecology. A multicentre clusterrandomised trial has been proposed [12]; this might usefully include a factorial design with blinding of the SDD component to explore potential synergies between interventions rather than a straight head-to-head comparison. Such a trial might finally allow us to move from practice based on 'gut instinct' to evidence-based medicine.

\section{Abbreviations}

SDD: Selective digestive decontamination; VAP: Ventilator-associated pneumonia.

\section{Competing interests}

The author declares that he has no competing interests.

Published: 19 Dec 2013

\section{References}

1. Cuthbertson BH, Campbell MK, Maclennan G, Duncan EM, Marshall AP, Wells EC, Prior ME, Todd L, Rose L, Seppelt IM, Bellingan G, Francis JJ: Clinical stakeholders' opinions on the use of selective decontamination of the digestive tract in critically ill patients in intensive care units: an international Delphi study. Crit Care 2013, 17:R266.

2. van Saene HKF, Stoutenbeek CP, Miranda DR, Zandstra DF: A novel approach to infection control in the intensive care unit. Acta Anaesthiol Belg 1983, 34:193.

3. Stoutenbeek CP, van Saene HK, Miranda DR, Zandstra DF: The effect of selective decontamination of the digestive tract on colonisation and infection rate in multiple trauma patients. Intensive Care Med 1984, 10:185-192.

4. Dellinger RP, Carlet JM, Masur H, Gerlach H, Calandra T, Cohen J, Gea-Banacloche J, Keh D, Marshall JC, Parker MM, Ramsay G, Zimmerman JL, Vincent JL, Levy MM: Surviving Sepsis Campaign guidelines for management of severe sepsis and septic shock. Intensive Care Med 2004, 30:536-555.

5. Dellinger RP, Levy MM, Carlet JM, Bion J, Parker MM, Jaeschke R, Reinhart K, Angus DC, Brun-Buisson C, Beale R, Calandra T, Dhainaut JF, Gerlach H, Harvey M, Marini JJ, Marshall J, Ranieri M, Ramsay G, Sevransky J, Thompson BT, Townsend S, Vender JS, Zimmerman JL, Vincent JL, International Surviving Sepsis Campaign Guidelines Committee: Surviving Sepsis Campaign: international guidelines for management of severe sepsis and septic shock. Crit Care Med 2008, 36:296-327.

6. Jaeschke R, Guyatt GH, Dellinger P, Schünemann H, Levy MM, Kunz R, Norris $\mathrm{S}$, Bion J: Use of GRADE grid to reach decisions on clinical practice guidelines when consensus is elusive. BMJ 2008, 337:327-337.

7. Dellinger RP, Levy MM, Rhodes A, Annane D, Carcillo JA, Gerlach H, Opal S, Sevransky J, Sprung CL, Douglas IS, Jaeschke R, Osborn TM, Nunnally M, Townsend SR, Reinhart K, Kleinpell RM, Angus DC, Deutschman CS, Machado FR, Rubenfeld G, Webb S, Beale RJ, Vincent IL, Moreno R, the Surviving Sepsis Campaign Committee: Surviving Sepsis Campaign: international guidelines for management of severe sepsis and septic shock. Intensive Care Med 2013, 39:165-228.

8. de Smet AM, Kluytmans JA, Blok HE, Mascini EM, Benus RF, Bernards AT, Kuijper EJ, Leverstein-van Hall MA, Jansz AR, de Jongh BM, van Asselt GJ, Frenay IH, Thijsen SF, Conijn SN, Kaan JA, Arends JP, Sturm PD, Bootsma MC, Bonten MJ: Selective digestive tract decontamination and selective oropharyngeal decontamination and antibiotic resistance in patients in intensive-care units: an open-label, clustered group-randomised, crossover study. Lancet Infect Dis 2011, 11:372-380.

9. Ochoa-Ardila ME, García-Cañas A, Gómez-Mediavilla K, González-Torralba A, Alía I, García-Hierro P, Taylor N, van Saene HK, de la Cal MA: Long-term use of selective decontamination of the digestive tract does not increase antibiotic resistance: a 5-year prospective cohort study. Intensive Care Med 2011, 37:1458-1465.

10. Houben AJ, Oostdijk EA, van der Voort PH, Monen JC, Bonten MJ, van der Bij AK, on behalf of the ISIS-AR Study Group: Selective decontamination of the oropharynx and the digestive tract, and antimicrobial resistance: a 4 year ecological study in 38 intensive care units in the Netherlands. $J$ Antimicrob Chemother 2013 [Epub ahead of print].

11. Silvestri $L$, van Saene HKF: Selective decontamination of the digestive tract does not increase resistance in critically ill patients: evidence from randomized controlled trials. Crit Care Med 2006, 34:2027-2030.

12. Daneman N, Sarwar S, Fowler RA, Cuthbertson BH, SuDDICU Canadian Study Group: Effect of selective decontamination on antimicrobial resistance in intensive care units: a systematic review and meta-analysis. Lancet Infect Dis 2013, 13:328-341.

13. The Matching Michigan Collaboration: 'Matching Michigan': a two-year stepped interventional programme to minimise central venous catheterblood stream infections in intensive care units in England. BMJ Qual Saf 2012, 22:110-123. 
14. Dixon-Woods M, Leslie M, Bion J, Tarrant C: What counts? An ethnographic study of infection data reported to a patient safety program. Milbank Quarterly 2012, 90:548-591.

15. Dixon-Woods M, Leslie M, Tarrant C, Bion J: Explaining Matching Michigan: an ethnographic study of a patient safety program. Implementation Sci 2013, 8:70.

16. Carlet J: The gut is the epicentre of antibiotic resistance. Antimicrob Resist Infect Control 2012, 1:39.

17. Silvestri L, de la Cal MA, van Saene HK: Selective decontamination of the digestive tract: the mechanism of action is control of gut overgrowth. Intensive Care Med 2012, 38:1738-1750.

$10.1186 / \mathrm{cc} 13165$

Cite this article as: Bion: Gut instinct. Critical Care 2013, 17:1025 